\title{
Changes in the Chemistry of the Weija Dam Reservoir in Ghana, Twenty Years after Impoundment
}

\author{
O. D. Ansa-Asare* and K. A. Asante \\ CSIR-Water Research Institute, P. O. Box 38, Achimota-Accra, Ghana \\ * Corresponding author
}

\begin{abstract}
The studies of the changes in Weija lake waters after 20 years of impoundment, were aimed at examining the status in the chemical characteristics of the Weija lake, by analysing available data collected over a 5-year period (1993-1997), and comparing them with the first 5 years of impoundment between 1977 and 1982. The study showed supersaturated dissolved oxygen concentrations, indicating the lake waters had recovered from the initial low oxygen saturation during the first few years of impoundment. The lake waters had high oxygen demand from the high phytoplankton levels and organic matter in the dry season. Chlorophyll 'a', which is an indication of algal biomass content, correlated with total inorganic carbon (alkalinity), giving a correlation coefficient of 0.61 at $95 \%$ confidence limit, reflecting the fact that both parameters decreased in the rainy season, and were higher in the dry season. The initial high concentration of nutrients also decreased after 20 years with the exception of nitrate, which concentration increased at the rate of $1.07 \mathrm{mg} \mathrm{l}^{-1}$ year ${ }^{-1}$ over the last 5 years, a condition that could mainly be attributed to nitrogen input from domestic and agricultural origin. The high seasonal trend of nitrate in the months of March and May was due to the fact that the period is the main farming season in the Weija catchment area when most fertilizers are applied. With respect to the major ions, slight increases in their concentrations occurred. Ionic concentration patterns were found to be $\mathrm{Na}>\mathrm{Ca}>\mathrm{Mg}>\mathrm{K}$ and $\mathrm{HCO}_{3}>\mathrm{Cl}>\mathrm{SO}_{4}$. The cationic pattern was in contrast to the previously reported pattern of $\mathrm{Na}>\mathrm{Mg}>\mathrm{Ca}>\mathrm{K}$, showing complete mixing of the lake waters with moderate rock weathering rate but a strong influence of maritime-derived salts.

\section{Introduction}

The Weija Dam was built across the River Densu at Weija in 1977 to satisfy the ever-increasing demand for hydroelectric power, and water for domestic, industrial and agricultural purposes.

The Weija Dam reservoir, hereafter called the Weija lake, has a surface area of about 310 ha (Fig. 1), and a depth ranging from 1 to $7 \mathrm{~m}$, and is almost at the mouth of $116 \mathrm{~km}$ long River Densu. The river source is from the AtewaAtwiredu mountain range in the Eastern Region of Ghana. It discharges into the Gulf of Guinea, partly through the Sakumo 1 lagoon at Bortianor, $10 \mathrm{~km}$ from the mouth of the River Densu. Soils are sodium Vleisols, coastal savanna Ochrosols and Lithosols (Ayibotele \& Tuffour-Darko, 1979; Ahn, 1970). However, the CSIR-Soil Research Institute described the major soil types in the Weija area as belonging to the Ayensu-Chichiwere soil type. It is mottled grey in colour, heavy alluvial clay, coarse and fine sandy leaves. The reservoir was created primarily for domestic and industrial water supply to serve the western part of the Greater Accra metropolitan area, but it is also used for irrigation and fisheries.
\end{abstract}




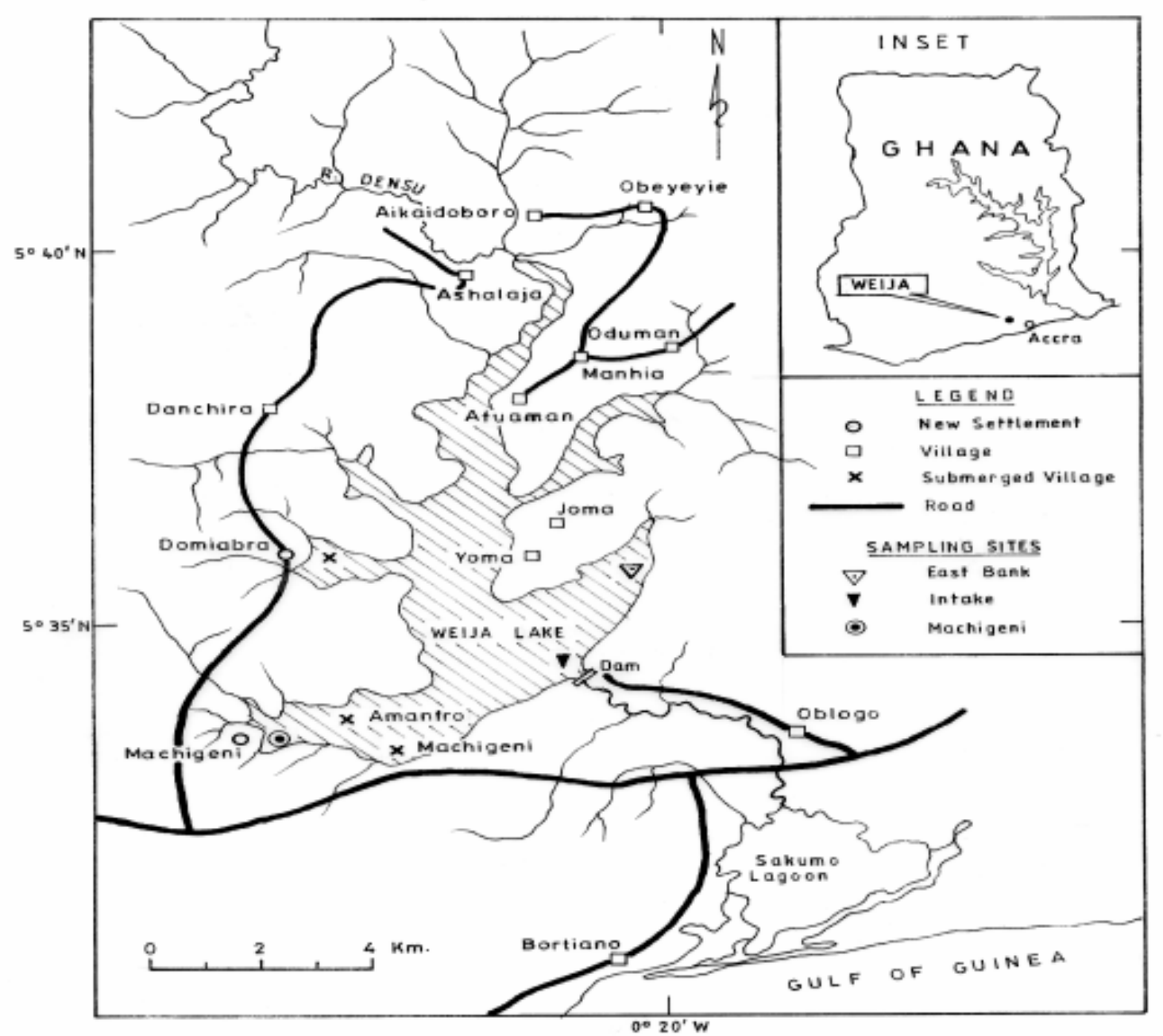

Fig. 1. The Weija lake and project area showing sampling sites

The area covered by the Weija lake in the coastal savanna plain has a low (800 mm p.a.) erratic bi-modal peak rainfall in May-June and October. The hottest months are February-April, with the highest mean monthly temperature of $32{ }^{\circ} \mathrm{C}$ occurring in March. The lowest mean monthly tempera-ture of $21.7{ }^{\circ} \mathrm{C}$ occurs in August. Information on the chemical quality of the lake water (Biney, 1987; Ansa-Asare, \& Asante 1998; Ansa-Asare, Marr \& Cresser, 1999) relates to the period prior to and after impoundment.

The main economic activities in the catchment of the reservoir are fishing and crop farming. Major crops include maize, cassava, sugar cane, pineapple and vegeta-bles. Fertilizers (nitrate and phosphate based) are used in cultivating some of the cereals and pineapple. Domestic effluents are also discharged into the lake waters without treatment.

The objective of the study is to enable a better understanding of the chemistry of the lake waters and to contribute to the knowledge of coastal tropical lakes by the use of chemical parameters such as surface water temperatures, nutrient dominant patterns, oxygen, etc. This paper examines the changes in the chemical characteristics of the Weija lake by analysing available data collected over a 5-year period (1993-1997) and comparing them with the first 5 years of impoundment, between 1977 and 1982, published by Biney (1987).

\section{Calculation of flows and turnover times for Weija lake}

\section{Materials and methods}

The catchment area (Weija lake) $=31,000,000 \mathrm{~m}^{2}$ (310 ha)

Standard average annual rainfall $(\mathrm{SAAR})=800 \mathrm{~mm}$

Potential evapotranspiration $(\mathrm{PE})=300 \mathrm{~mm}$

Effective runoff $=500 \mathrm{~mm}$

Calculation of annual runoff: $500 \mathrm{~mm}$ from $1 \mathrm{~m}^{2}=500,000 \mathrm{~cm}^{3}=500 \mathrm{~lm}^{2} \mathrm{y}^{1}$

Expected runoff from:

Total area $=1.55 \times 10^{10} \mathrm{l} \mathrm{y}^{-1}$

Mean inflow $=54.2 \mathrm{~m}^{3} \mathrm{~s}^{-1}\left(1 \mathrm{~m}^{3}=1000 \mathrm{l}\right)=54200 \mathrm{l} \mathrm{s}^{-1}$ 
Total annual inflow $=54200 \times 60 \times 60 \times 24 \times 365=170.9310^{10} \mathrm{ly}^{-1}$

Turnover time (based on effective runoff):

For an average depth of $6.5 \mathrm{~m}$ of Weija lake and an area of 3,000,000 $\mathrm{m}^{2}$, then the total volume $=2.01510^{10} \mathrm{l} 471$ days.

The turn over time (based on effective runoff) for Weija lake (assuming average rainfall is evenly distributed) is about 471 days.

\section{Procedure}

The authors developed the research as part of the Global Environmental Monitor-ing System (GEMS) Water Project in assessing lakes and reservoirs in Ghana. The Weija lake ( $5^{\circ} 35^{\prime}-5^{\circ} 40^{\prime} \mathrm{N}$ and $\left.0^{\circ} 20^{\prime}-0^{\circ} 24^{\prime} \mathrm{W}\right)$ lies $17 \mathrm{~km}$ west of Accra (Fig. 1), and is used as a source of drinking water for nearly 1,000,000 persons, as well as for irrigation and bathing.

The sampling period extended from January 1993 to November 1997. The sampling frequency was six times yearly for 5 years. Water samples were collected between 8 and $10 \mathrm{~h}$ in the morning, at $30 \mathrm{~cm}$ depth from the surface and the bottom of the lake, and samples were collected into clean $500 \mathrm{ml}$ plastic bottles. The temperature and $p \mathrm{H}$ were determined in situ, using a mercury-in-glass thermometer and a portable $p \mathrm{H}$ meter. For dissolved oxygen (DO) determination, separate samples were collected in plain glass bottles and the azide modification of the Winkler method used. Samples for biochemical oxygen demand (BOD) were collected in dark glass bottles and incubated at $20{ }^{\circ} \mathrm{C}$ for 5 days after which DO was determined. All nutrients were analysed within $0.9-1.9 \%$ relative standard deviation (rsd), using colourimetric methods, (APHA, 1975).

Standard techniques (APHA, 1975) were used to analyse the different parameters: electrical conductivity (EC, measured at $25{ }^{\circ} \mathrm{C}$ ), total dissolved solids (TDS, evaporated at $105{ }^{\circ} \mathrm{C}$ ), Ca and $\mathrm{Mg}$ (EDTA titrimetric method), $\mathrm{Cl}$ (argentometric method) and alkalinity (Alk, titrimetric method).

Individual seasons were defined as the rainy season (April-July, and September and October) and the dry season (November- March). Major ion characterisation of the lake was from 1997 data, and statistical analyses were performed on all the data. Because some data do not indicate any trend or cyclical fluctuations, seasonal indices for nutrients were calculated (Bajpai, 1967) as illustrated in Table 4 for silicate. Yearly mean in $\mathrm{mg} \mathrm{l}^{-1}$ was computed, followed by 5-year average, then the average of the monthly averages were also obtained. The monthly means were expressed as a percentage by taking the average of these means to give the seasonal index (SI). Thus, the SI for silicate in January was:

$$
(4.96100) / 5.42=91.5
$$

The buffering capacity of the lake was calculated using the criteria defined by Jeffries et al. (1986), who characterised lake sensitivity to acidification in terms of acid neutralising capacity (ANC) as defined below:

ANC $=\sum$ base cations $-\sum$ strong acid anions

$$
=([\mathrm{Ca}]+[\mathrm{Mg}]+[\mathrm{Na}]+[\mathrm{K}])-
$$

$$
\left(\left[\mathrm{SO}_{4}\right]+\left[\mathrm{NO}_{3}\right]+[\mathrm{Cl}]\right)
$$

Jeffries et al. (1986) used an ANC scale defined as follows:

ANC $\leq 0=$ Acidified

ANC $0-40 \mathrm{mmol}_{\mathrm{c}} \mathrm{l}^{-1}=$ Very sensitive

ANC $40-200$ mmol $_{\mathrm{c}} \mathrm{l}^{-1}=$ Sensitive

ANC $>200 \mathrm{mmol}_{\mathrm{c}} \mathrm{l}^{-1}=$ Insensitive $^{-1}$

\section{General lake characteristics}

\section{Results and discussion}

The main economic activities in the catchment of the reservoir are fishing and crop farming. Fertilizers (nitrate and phosphate based) are used in cultivating some of the cereals. Domestic waste waters are also discharged into the reservoir. Table 1 shows inputs by the major settlements along the Weija lake catchment. Inputs were calculated to determine their significance. The WHO rapid assessment method for polluted waters (Suess, 1982) was used for the computations. These were compared with the main inflow river loads. Based on population estimates supplied by the Statistical Service, Ghana (2000), the loads per capita per day were used to compute nutrient inputs from settlements to the Weija lake (Table 1). These showed a significant contribution from the main inflow river (the Densu) to Weija lake. Note that the population growth rate of the Greater Accra Region is 3.57 per annum. 
TABLE 1

Nutrient inputs from settlements compared with that of river Densu and Weija lake waters

$\begin{array}{lllll}\begin{array}{l}\text { Catchment } \\ \text { population } \\ (1997) *\end{array} & \text { Settlement } & \begin{array}{l}\text { Total } N \\ \left(\mathrm{~kg} \mathrm{day}^{-1}\right)\end{array} & \begin{array}{l}\text { Total } P \\ \left(\mathrm{kgday}^{-1}\right)\end{array} & \begin{array}{l}\text { Biochemical oxygen demand } \\ \left(\mathrm{kgday}^{-1}\right)\end{array} \\ 3919 & \text { Weija } & 47.0 & 11.8 & 235.1 \\ 1109 & \text { Manhia } & 13.3 & 3.3 & 66.5 \\ 1069 & \text { Afuaman } & 12.8 & 3.2 & 64.1 \\ 1024 & \text { Domiabra } & 12.3 & 3.1 & 61.4 \\ & \text { River Densu } & 15,629 & 3,336 & 6,718 \\ & \text { Lake water } & 8,225 & 275.3 & 31,726\end{array}$

* 1997 population estimates supplied by Statistical Service, Ghana

Based on samples analysed, the descriptive statistics of parameter values for the 5-year period have been displayed in Table 2. The data show the extent of temporal variability in the composition of lake waters. Using Jeffries calculations, the Weija lake was found to be insensitive with a mean value of $1.615 \mathrm{mmol}_{\mathrm{c}} \mathrm{l}^{-1}$. This is related to the surrounding geology or the use of lime on farms. Alkalinity and $\mathrm{pH}$ values in Table 2 confirm this condition.

TABLE 2

\begin{tabular}{|c|c|c|c|c|c|c|}
\hline Parameter & Mean & $S D$ & Min. & Max. & $C V$ & $N$ \\
\hline$p \mathrm{H}$ & 7.5 & 0.608 & 6.2 & 8.7 & 0.080 & 30 \\
\hline $\mathrm{EC}\left(\mathrm{mS} \mathrm{cm} \mathrm{cm}^{-1}\right)$ & 360 & 109 & 270 & 770 & 0.305 & 30 \\
\hline TDS & 173 & 37.7 & 134 & 333 & 0.218 & 30 \\
\hline $\mathrm{Ca}^{2+}$ & 20.1 & 10.7 & 12.8 & 56.4 & 0.533 & 30 \\
\hline $\mathrm{Mg}^{2+}$ & 15.1 & 3.95 & 6.4 & 25.4 & 0.261 & 30 \\
\hline Alk & 120 & 20.7 & 100 & 1800.172 & 30 & \\
\hline $\mathrm{SO}_{4}^{2-}$ & 13.5 & 5.62 & $<0.002$ & 21.6 & 0.413 & 30 \\
\hline $\mathrm{Cl}^{-}$ & 45.9 & 8.12 & 34.0 & 74.0 & 0.177 & 30 \\
\hline DO & 9.0 & 2.24 & 5.1 & 13.0 & 0.249 & 30 \\
\hline $\mathrm{BOD}_{5}$ & 6.8 & 2.39 & 1.2 & 12.1 & 0.351 & 30 \\
\hline $\mathrm{NH}_{4}-\mathrm{N}$ & 0.160 & 0.169 & $<0.002$ & 0.56 & 1.06 & 30 \\
\hline $\mathrm{NO}_{2}-\mathrm{N}$ & 0.533 & 2.13 & $<0.002$ & 10.7 & 4.01 & 30 \\
\hline $\mathrm{NO}_{3}-\mathrm{N}$ & 1.07 & 1.56 & $<0.002$ & 4.96 & 1.46 & 30 \\
\hline $\mathrm{PO}_{4}-\mathrm{P}$ & 0.059 & 0.069 & $<0.002$ & 0.2 & 1.17 & 30 \\
\hline $\mathrm{SiO}_{2}$ & 5.55 & 4.43 & 0.2 & 15.2 & 0.798 & 30 \\
\hline Temperature ${ }^{\circ} \mathrm{C}$ & 30.1 & 1.69 & 26.2 & 34.0 & 0.056 & 30 \\
\hline Hardness & 78.8 & 15.9 & 44 & $120 \quad 0.201$ & 30 & \\
\hline Transparency (m) & 0.71 & 0.104 & 0.60 & 1.00 & 0.147 & 30 \\
\hline
\end{tabular}

SD: standard deviation; CV: coefficient of variation; n: number of samples

The $p \mathrm{H}$ of Weija lake varied between 6.2 and 8.7, with the minimum value observed in January. The average content of total dissolved solids (TDS) was $173 \mathrm{mg} \mathrm{l}^{-1}$ (varying between 134 and $333 \mathrm{mg} \mathrm{l}^{-1}$ ). Parameters relating to organic matter in water exhibited a considerable variability (CV $=0.35-4.0 \mathrm{mg} \mathrm{l}^{-1}$ on average) with nitrite and nitrate displaying the extreme variability (CV up to 4.10). The CV was lower for Ca and Mg, EC and TDS (CV < 0.329 on average). The variability of water quality parameters was larger for the organic matter related parameters compared to the inorganic ones (major and minor elements). This variability is greatly influenced by seasonal variation.

When anomalous values were discarded, specific conductance was found to be fairly well correlated $(r=0.829)$ with total dissolved solids (TDS). The slope was 0.393, outside the normally reported range of 0.55-0.70 (APHA, 1980, 1985) but this deviation was not unexpected because TDS values do not include silica, but the main cause may be attributed to alkalinity. The most important single ion contribution to conductivity was chloride $(r=0.717)$ and the least contribution was alkalinity $(r=0.459)$, which might be as a result of maritime aerosols. 
Pre-impoundment studies of the proposed Weija reservoir by Amuzu (1975) showed low dissolved oxygen concentrations with a mean saturation level of about 20\%. Biney (1987), in his study of the changes in the chemistry of the Weija lake, also reported low oxygen saturation persistence during the first year of the closure of the dam. This situation was attributed to the proliferation of floating mats of aquatic vegetation, mainly Pistia stratiotes, and excess nutrients brought into the solution by the decomposition of organic matter and dissolution of inorganic salts from soil and rock, which produced an initial explosive multiplication of both aquatic plants and animals. However, the period of low oxygen in the Weija lake came to an end during the second year of impoundment. Studies conducted between 1979, the second year of impoundment, and 1981 showed annual mean oxygen saturation levels ranging from 85 to 90\%. This trend continued through 1982, 5 years after impoundment. In this study, about 10 years later (1993-1997), the annual mean oxygen saturation levels ranged from 64 to 163\% (Fig. 2). This regular trend had persisted over the years as a result of the high algal biomass content (Ansa-Asare, 1998) in the lake waters and also diurnal variation of the cycling nature of dissolved oxygen reflecting in the spot measurement of sampling.
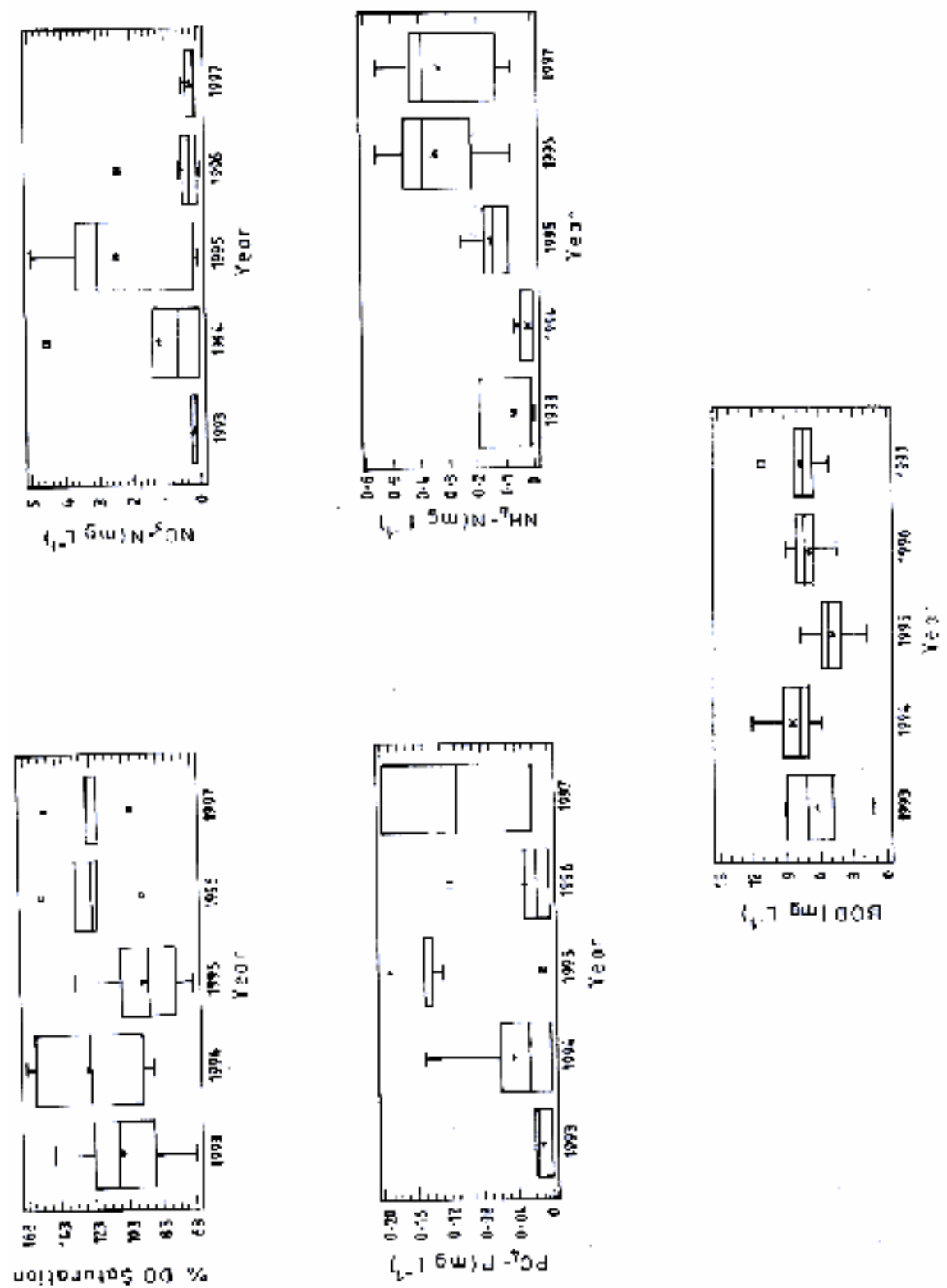

Fig. 2. Box and Whisker plots of $\mathrm{Ca}, \mathrm{Mg}, \mathrm{SO}_{4}$, Alk and $\mathrm{Cl}$ between 1993 and 1997 for Weija lake sampled six times a year. Stars in boxes are means, tops and bottoms of boxes represent the 25th and 75th percentiles, whiskers represent the 90th and 10th percentiles, and lines in boxes are medians.

Studies conducted by Ansa-Asare (1998) on the correlation matrix between DO, $p \mathrm{H}$ and other parameters for Weija through monthly spot measurements, with sample size of 60, with monthly sampling interval for a period of 5 years, showed increased oxygen production in the lake waters with high algal density. But biomass, which was related 
directly to turbidity, had high BOD levels. There was no correlation between $\mathrm{DO}$ and $p \mathrm{H}$, perhaps, because of the sampling times or the cycling nature of DO and $p \mathrm{H}$ during the day as identified by Ansa-Asare (1998).

The relative stabilisation of the Weija lake and the maintenance of higher oxygen concentrations as compared to the pre-impoundment and immediate post-impoundment periods are attributable to the reduction in nuisance weeds and decaying organic material. Seasonal variation of dissolved oxygen by Ansa-Asare \& Asante (1998) showed higher concentrations of dissolved oxygen in March (10.4 $\left.\mathrm{mg} \mathrm{l}^{-1}\right)$, reflecting high phytoplankton populations, which will be confirmed later by the biomass content in the lake waters. The well-oxygenated waters of the Weija lake reflect a combination of strong wind turbulence and high photosynthetic activity (Fig. 2).

Weija lake had high BOD concentrations (Fig. 2). The 5-year monthly mean was between 5.48 in July and $8.16 \mathrm{mg}$ $\mathrm{l}^{-1}$ in March (Ansa-Asare \& Asante, 1998). The highest yearly BOD concentration for the Weija lake was $8.4 \mathrm{mg} \mathrm{l}^{-1}$ (1994) and the lowest was $5.1 \mathrm{mg} \mathrm{l}^{-1}$ (1995).

Unfortunately, for the period 1983-1992 there are no data for DO and BOD to comment on but, in general, there has been tremendous improvement in land use and fertilizer application in the catchment area of the Weija lake, compared to the pre-impoundment era. The high BOD load from the River Densu (Table 1) was a result of dumping of refuse and domestic waste water into the river course upstream.

\section{Nutrients}

The mean concentration of dissolved inorganic phosphate prior to impoundment was above $0.6 \mathrm{mg} \mathrm{l}^{-1}$ (Biney, 1987), which was higher as a result of the washing of phosphate-rich fertilizer from farms in the catchment zone into the Densu river. The concentration of nitrate was also high during this period. Thus, the high concentration of dissolved nutrients was able to support the nuisance growth of aquatic plants, notably Pistia stratiotes. High concentrations of ammonia-nitrogen were also recorded at the Weija lake in 1976 and 1977 by Biney (1987).

There was a reduction in concentration of phosphate and nitrate in 1982, 5 years after impoundment. The reduction in concentration of nitrate during this period coincided with the recovery from low oxygen saturation levels of the lake. However, during the last 5 years of the study, nitrate concentration has increased to a mean of $1.07 \mathrm{mg} \mathrm{l}^{-1}$ per year. This could be attributed to the continued effects of the inundation of arable land and the leaching of fertilizer into the lake water.

In the present study, there has been a drastic reduction of phosphates to a mean of $0.059+0.07 \mathrm{mg} \mathrm{PO}_{4}-\mathrm{P} \mathrm{l}^{-1}$ (Table 1). This phenomenon could be partly explained by the fact that phytoplankton growth in the Weija lake reduced the levels of orthopho-sphate. The generally moderate concentra-tions of phosphate and ammonia-nitrogen may also be explained by the fact that they could be confined to bottom waters as a result of the decomposition of organic matter in the sediments.

The high mean concentrations of nitrate were biased by the variability of the individual measured nitrate concentration because from Fig. 2 most of the values were low. The con-dition explains the complex nature of the nitrification process in lake waters. It is clear that there was a gradual increase in ammonia-nitrogen, suggesting more organic nitrogen input from domestic and agricultural origin (Fig. 2), and seasonal indices for Weija lake by AnsaAsare \& Asante (1998) showed high indices of nutrient in the rainy season and low values in the dry season. The concentration of $\mathrm{N}$ and $\mathrm{P}$ fluctuated during the study period, resulting in nitrogen and phosphorus being limiting nutrients in the Weija lake (Ansa-Asare, 1998). According to Meybeck, Chapman \& Helmer (1989), in waters with a total inorganic N/P ratio greater than 7-10, phosphorus will be limiting, whereas nitrogen will be limiting in the lake with a total inorganic N/P ratio below 7.

One of the objectives of creating the Weija lake was the development of fisheries or aquaculture. Although there were fluctua-tions in the nutrient levels (Table 3) in the lake waters after 20 years of impound-ment, their present levels should still support aquaculture development. However, the relatively high nutrient concentration has a bit of nuisance for potable water supply.

TABLE 3

Mean chemical analysis of surface and bottom waters

\begin{tabular}{lccccccc}
\multicolumn{2}{c}{ Surface } & & & & \multicolumn{2}{c}{ Bottom } \\
& Machigeni & Weija & Domiabra & Machigeni & Weija & \multicolumn{2}{c}{ Domiabra } \\
$\mathrm{O}_{2}$ (\% satn.) & $113 \%$ & $112 \%$ & $112 \%$ & $90 \%$ & $85 \%$ & $99 \%$ & 7.9 \\
$\mathrm{O}_{2}$ (mg l-1) & 9.0 & 8.9 & 8.9 & & 7.2 & 0.8 & 0.05 \\
$\mathrm{PO}_{4}-\mathrm{P}\left(\mathrm{mg} \mathrm{l}^{-1}\right)$ & 0.26 & 0.16 & 0.17 & & 0.06 & 0.15 & 0.07 \\
$\left.\mathrm{NO}_{3}-\mathrm{N} \mathrm{(mg} \mathrm{l-1}\right)$ & 0.25 & 0.18 & 0.16 & & 0.06 &
\end{tabular}




\begin{tabular}{|c|c|c|c|c|c|c|c|}
\hline $\mathrm{NH}_{4}-\mathrm{N}\left(\mathrm{mg} \mathrm{l}^{-1}\right)$ & $<0.001$ & 0.10 & 0.05 & $<0.001$ & 0.05 & 0.14 & \\
\hline $\mathrm{Ca}^{2+}($ meq l-1) & 0.94 & 0.89 & 0.91 & & 0.79 & 0.84 & 0.89 \\
\hline $\mathrm{Mg}^{2+}\left(\right.$ meq $\left.\mathrm{l}^{-1}\right)$ & 0.78 & 0.95 & 0.97 & & 0.77 & 0.78 & 0.87 \\
\hline $\mathrm{Na}^{2+}($ meq l-1) & 1.4 & 1.5 & 1.5 & & 1.4 & 1.5 & 1.6 \\
\hline $\mathrm{K}^{+}\left(\right.$meq $\left.\mathrm{l}^{-1}\right)$ & 0.15 & 0.15 & 0.16 & & 0.11 & 0.14 & 0.12 \\
\hline $\mathrm{HCO}_{3}^{-}($meq l-1) & 1.7 & 1.8 & 1.9 & & 1.7 & 1.8 & 1.8 \\
\hline $\mathrm{C}^{-}($meq l-1) & 1.6 & 1.7 & 1.7 & & 1.7 & 1.7 & 1.7 \\
\hline $\mathrm{SO}_{4}^{2-}\left(\mathrm{meq}^{-1}\right)$ & 0.44 & 0.45 & 0.40 & & 0.44 & 0.40 & 0.40 \\
\hline
\end{tabular}

\section{Seasonal indices of nutrient}

Studies conducted by Ansa-Asare \& Asante (1998) showed that the seasonal indices for Weija were high in the rainy season and low in the dry season (Table 4 and 5). However, the phosphate index in January was high, and the high index in March was due to rain in the latter part of that month. Ammonia-nitrogen in November also showed high indices because November is immediately after the rainy season so some effects of the rain persisted. The high seasonal trend of nitrates in the months of March and May (Tables 4 and 5) was due to the main ploughing periods for farming in the Weija catchment area when most fertilizer is applied.

TABLE 4

Seasonal index of silicate for Weija

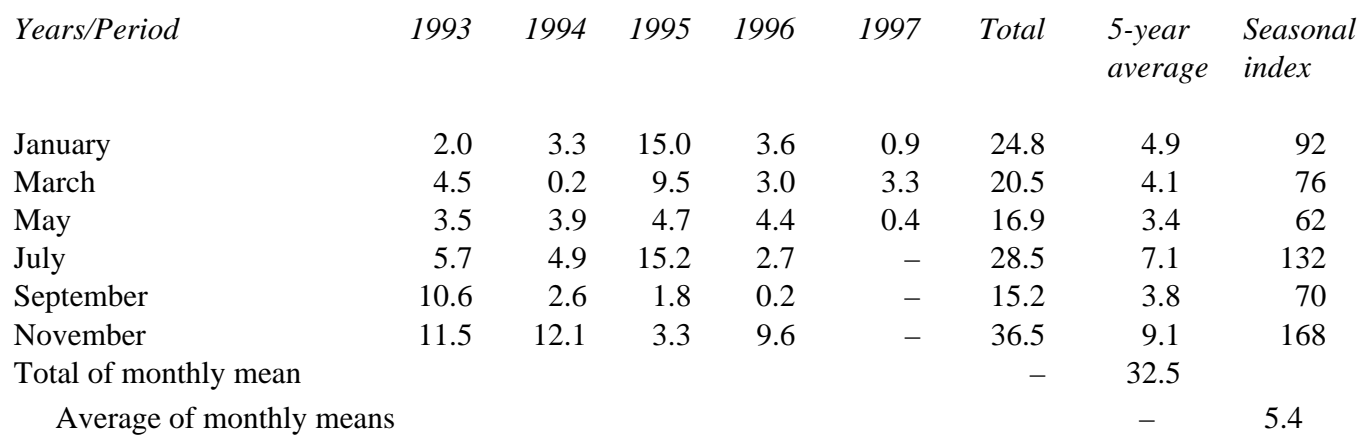

TABLE 5

Seasonal indices for Weija

$\begin{array}{lrcrrr}\text { Month } & \text { Nitrate } & \begin{array}{c}\text { Ammonium } \\ \text { Nitrogen }\end{array} & \text { Phosphate } & \text { Sulphate } & \text { Silicate } \\ \text { January } & 23 & 91 & 117 & 90 & \\ \text { March } & 127 & 86 & 67 & 63 & 76 \\ \text { May } & 202 & 205 & 83 & 79 & 62 \\ \text { July } & 36 & 82 & 150 & 134 & 132 \\ \text { September } & 112 & 32 & 67 & 104 & 70 \\ \text { November } & 102 & 105 & 133 & 128 & 169\end{array}$

Source: Ansa-Asare \& Asante (1998)

\section{Major ions}

Studies conducted before and after the closure of the Weija Dam showed the quality of water with respect to the major ions to be intermediate between fresh and seawater (Biney, 1987). The low concentrations of the major ions recorded at all times indicated that the waters were fresh as noted by Buckney \& Tyler, 1976 elsewhere. Comparison of the mean annual concen-trations of bicarbonate, chloride, sulphate and magnesium by Biney (1987) indicated slight increase, 5 years after impoundment.

Results of analyses conducted on major ions showed moderate weathering rate but with a strong influence of maritime-derived salts. The general ionic dominance patterns were found to be $\mathrm{Na}>\mathrm{Ca}>\mathrm{Mg}>\mathrm{K}$ and $\mathrm{HCO}_{3}>\mathrm{Cl}>$ $\mathrm{SO}_{4}$ (Fig. 3). This is in contrast to the ionic dominance patterns of $\mathrm{Na}>\mathrm{Mg}>\mathrm{Ca}>\mathrm{K}$ and $\mathrm{Cl}>\mathrm{SO}_{4}>\mathrm{HCO}_{3}$ for seawater and $\mathrm{Ca}>\mathrm{Mg}>\mathrm{K}$ and $\mathrm{HCO}_{3}>\mathrm{SO}_{4}>\mathrm{Cl}$ for fresh water (Stumm \& Morgan, 1981). Thus, both cationic and anionic patterns were intermediate between those of fresh and seawater. The dominance of chloride over sulphate could be mainly due to a strong atmospheric maritime aerosol input, together with fertilization, as well as domestic 
and anthropogenic point sources. The dominance of magnesium over calcium in pre-impoundment studies, persisted 5 years after impoundment although fluctua-tions may have occurred as recorded by Biney (1987) with dominance of calcium over magnesium, which was due to weathering. A comparison of the mean annual concentrations of the base cations with that reported by Biney (1987) shows that there was virtually no change after a period of 10 years.
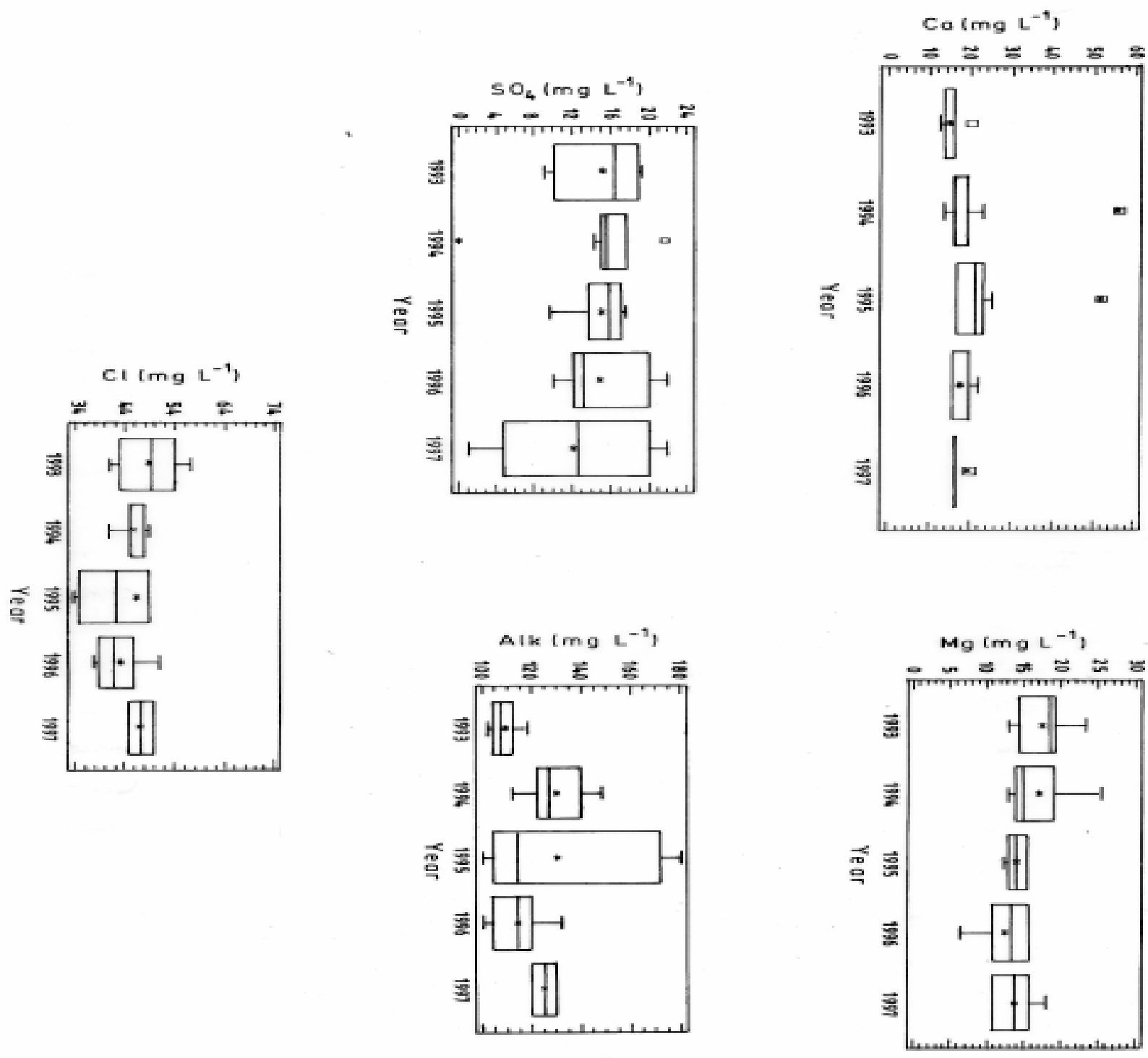

Fig. 3. Box plots of $\mathrm{DO}, \mathrm{NO}_{3}-\mathrm{N}, \mathrm{PO}_{4}-\mathrm{P}, \mathrm{NH}_{4}-\mathrm{N}$ and $\mathrm{BOD}$ between 1993 and 1997 for Weija lake sampled six times a year. Stars in boxes are means, tops and bottoms of boxes represent the 25th and 75th percentiles, whiskers represent the 90th and 10th percentiles, and lines in boxes are medians.

Generally, while the mean annual concentrations of calcium, sodium and potassium remained constant, that of magnesium decreased over the five-year period. Weija lake also showed a significant correlation between Ca and $\mathrm{Mg}$, $r=0.5(p=0.0133)$ at $95 \%$ confidence level which was an indication of weathering input into the lake waters for both of these base cations.

\section{Chlorophyll ' $a$ ' and other parameters}

The waters had a slightly high oxygen demand from the high phytoplankton levels and organic matter. Surface DO ranged from $5.1 \mathrm{mg} \mathrm{l}^{-1}$ to $13.0 \mathrm{mg} \mathrm{l}^{-1}$ with a bio-chemical oxygen demand range of $1.2 \mathrm{mg} \mathrm{l}^{-1}$ to $12.1 \mathrm{mg} \mathrm{l}^{-1}$. The high BOD was as a result of organic matter from diverse origin. Total inorganic carbon (TIC), comprising mainly carbonate or bicarbonate, ranged from $100 \mathrm{mg} \mathrm{l}^{-1}$ to $180 \mathrm{mg} \mathrm{l}^{-1}$, which was sufficient as a source of carbon for photosynthetic activity. Chlorophyll 'a' ranged from $55 \mathrm{mg} \mathrm{l}^{-1}$ at the beginning of the dry season to $330 \mathrm{mg} \mathrm{l}^{-1}$ in March, which was almost the end of the dry season (Ansa-Asare, 1998). From Fig. 4, it is clear that there was more chlorophyll in the dry season than in the rainy season. There was much dilution in the rainy season resulting in lower values of the other parameters. 


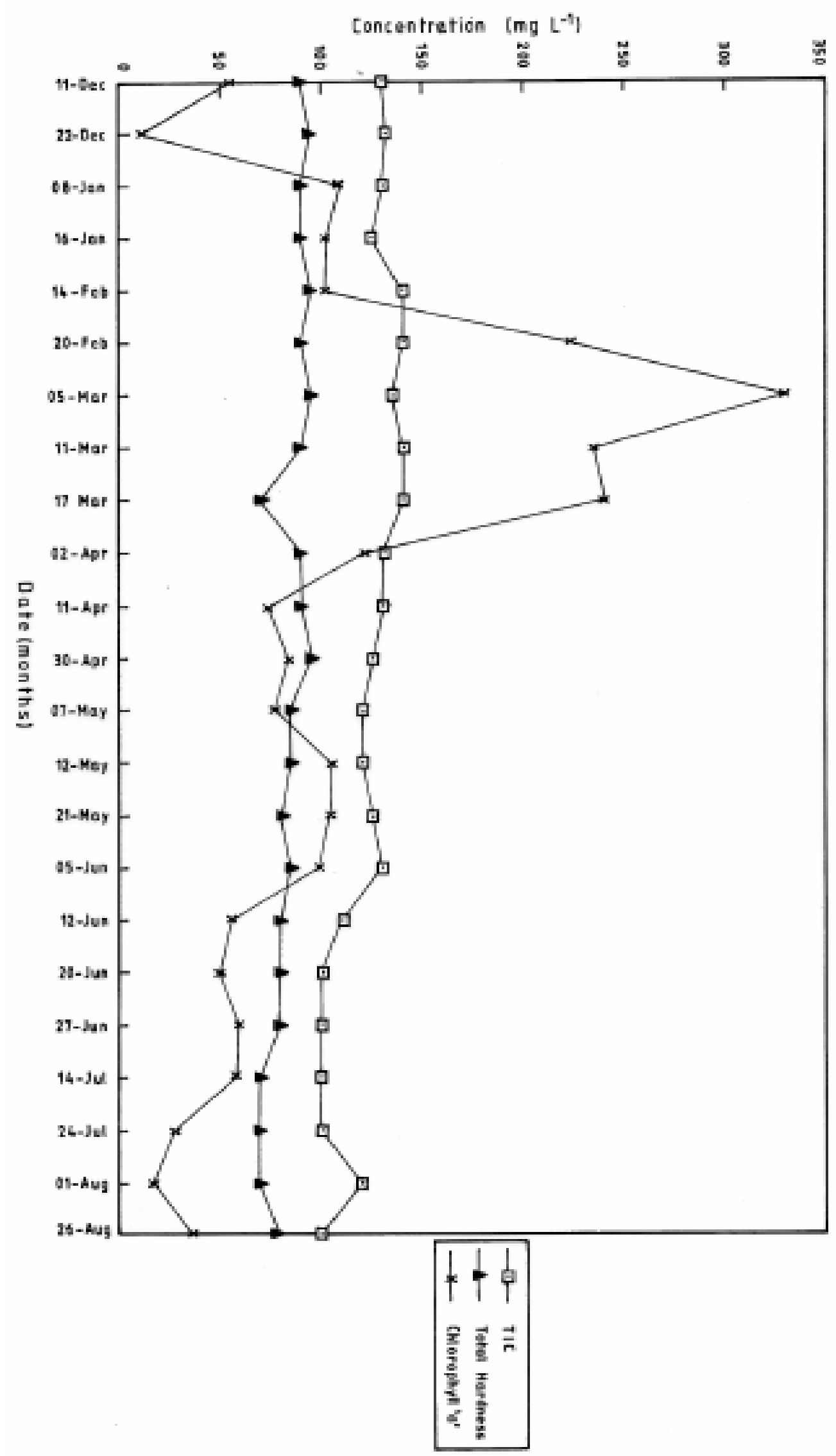

Fig. 4. Levels of chlorophyll 'a', total hardness and TIC in Weja lake (hardness expressed as $\mathrm{mg} \mathrm{l}^{-1} \mathrm{CaCO}_{3}$; TIC, and chlorophyll 'a' as mg l-1).

Chlorophyll 'a', which is an indicator of algal biomass content, correlated well with total inorganic carbon, giving a correlation coefficient of 0.61 at $95 \%$ confidence limits. This reflects the fact that both the para-meters declined in the rainy season, and were higher in the dry season. Most of the carbon in the water would have been cycled through organisms and plants. Biota result either directly or indirectly from photosynthesis. In fresh water bodies, typically, 
concentrations of few mg C l$^{-1}$ are encountered; waters low in $\mathrm{Ca}$ and $\mathrm{Mg}$ concentrations often contain humic substances, and organic carbon concentrations may be as high as $50 \mathrm{mg} \mathrm{Cl}^{-1}$ (Butler, 1982).

\section{Conclusion}

The lake waters had high oxygen demand from the high phytoplankton levels and organic matter in the dry season. Chlorophyll 'a', which is an indication of algal biomass content, correlated with total inorganic carbon (alkalinity), giving a correlation coefficient of 0.61 at $95 \%$ confidence limits, reflecting the fact that both parameters decreased in the rainy season, and were higher in the dry season. The levels of chlorophyll "a” found in the Weija lake ranged from 55-330 $\mathrm{mg} \mathrm{l}^{-1}$, which was far in excess of 0.005-0.300 $\mathrm{mg} \mathrm{l}^{-1}$ (classified as eutrophic by Chapman, 1997). Thus, it can be concluded that the Weija lake is eutrophic.

Nitrate increased to a mean of $1.07 \mathrm{mg} \mathrm{l}^{-1}$ per year, with a corresponding drastic reduction of phosphates during the last 5 years. This phenomenon could be explained by the fact that continued inundation of arable land coupled with the leaching of fertilizer into the lake water caused the decrease. The low phosphate could be explained in part by the fact that they could be confined to the bottom waters as a result of the decomposition of organic matter in sediments. One can then conclude that the quality of the lake waters has deteriorated after 20 years of impoundment.

\section{Acknowledgement}

The authors acknowledge the facilities provided by the former Institute of Aquatic Biology (CSIR). They wish to thank Messrs Sampson K. Abu, Humphrey F. Darko and Albert A. Essien for technical assistance during sampling and analyses. They are grateful to the Global Environmental Monitoring System (GEMS) Water Project, without which this study would not have been feasible.

\section{References}

Ahn P. M. (1970). West African Soils. London: Oxford University Press.

Amuzu A. T. (1975). A survey of the water quality of the river Densu. Accra, Ghana: Water Resources Research Unit. 1-57 pp.

Ansa-Asare O. D. (1998). Do dissolved oxygen cycles have diagnostic value for assessing pollution status in lakes? (PhD Thesis.) University of Aberdeen, Aberdeen. 208 pp.

Ansa-Asare O. D. and Asante K. A. (1998). A comparative study of the nutrient status of two reservoirs in southeast Ghana. Lakes Reserv. Res. Mgmt. 3: 205-217.

Ansa-Asare O. D., Marr, I. L. and Cresser, M. S. (1999). Evaluation of cycling patterns of dissolved oxygen in a tropical lake as an indicator of biodegradable organic pollution. The Science of the Total Environment 231: 145-158.

APHA WPCF (1975). Standard methods for the examination of water and wastewater, 11th edn. Washington DC: APHA, WPCF. pp. 273-978.

APHA WPCF (1980). Standard methods for the examination of water and wastewater. 14th edn. Washington DC: APHA, WPCF. pp. 520-750.

APHA WPCF (1985). Standard methods for the examination of water and wastewater, 16th edn. Washington DC. pp. 220-750.

Ayibotele N. B. and Tuffour- Darko, T. (1979). Sediment loads in southern rivers of Ghana. Accra, Ghana: Water Resources Research Unit. pp. 15-25.

Bajpai O. P. (1967). Foundations of Statistics. New York: Asia Publishing House. pp. 271-277.

Biney C. A. (1987). Changes in the chemistry of a tropical man-made lake, the Densu reservoir, during five years of impoundment. Trop. Ecol. 28: 222-231.

Buckney R. T. and Tyler P. A. (1976). Chemistry of salt lakes and other waters of

the sub-humid regions of Tasmania. Aust. J. mar. Freshwat. Res. 27: 359-366.

Butler J. N. (1982). Carbon dioxide equilibria and its applications. Reading, MA: Addison-Wesley Publ. Co.

Chapman D. (1997) Water Quality Assessments. London and New York: E \& FN Spon. 76 pp.

Jeffries D. S., Wales D. L. , Kels J. R. M. and Linthurst R. A. (1986). Regional characteristics of lakes in North America. Part 1 Eastern Canada. Wat. Air Soil Pollut. 31: 317-369.

Meybeck M., Chapman D. and Helmer R. (1989). Global freshwater quality. A first assessment, Oxford: Blackwell Reference. 306 pp.

Stumm W. and Morgan J. J. (1981). Aquatic Chemistry. New York: Wiley. 780 pp.

Suess M. (1982). Examination of Water for Pollution Control, vol. 1-3. Oxford: Pergamon Press. pp. 45-55.

Statistical Service Ghana (2000) The Population Census of Ghana. Accra: Statistical Service. 